\title{
RESEARCH
}

Open Access

\section{Zonal aspects of the influence of forest cover change on runoff in northern river basins of Central Siberia}

\author{
A. Onuchin ${ }^{1 *}$ DiD, T. Burenina ${ }^{1}$, A. Shvidenko ${ }^{1,2^{*}}$, D. Prysov ${ }^{1}$ and A. Musokhranova ${ }^{1}$
}

\begin{abstract}
Background: Assessment of the reasons for the ambiguous influence of forests on the structure of the water balance is the subject of heated debate among forest hydrologists. Influencing the components of total evaporation, forest vegetation makes a significant contribution to the process of runoff formation, but this process has specific features in different geographical zones. The issues of the influence of forest vegetation on river runoff in the zonal aspect have not been sufficiently studied.

Results: Based on the analysis of the dependence of river runoff on forest cover, using the example of nine catchments located in the forest-tundra, northern and middle taiga of Northern Eurasia, it is shown that the share of forest cover in the total catchment area (percentage of forest cover, FCP) has different effects on runoff formation. Numerical experiments with the developed empirical models have shown that an increase in forest cover in the catchment area in northern latitudes contributes to an increase in runoff, while in the southern direction (in the middle taiga) extensive woody cover of catchments "works" to reduce runoff. The effectiveness of geographical zonality in regards to the influence of forests on runoff is more pronounced in the forest-tundra zone than in the zones of northern and middle taiga.

Conclusion: The study of this problem allowed us to analyze various aspects of the hydrological role of forests, and to show that forest ecosystems, depending on environmental conditions and the spatial distribution of forest cover, can transform water regimes in different ways. Despite the fact that the process of river runoff formation is controlled by many factors, such as temperature conditions, precipitation regime, geomorphology and the presence of permafrost, the models obtained allow us to reveal general trends in the dependence of the annual river runoff on the percentage of forest cover, at the level of catchments. The results obtained are consistent with the concept of geographic determinism, which explains the contradictions that exist in assessing the hydrological role of forests in various geographical and climatic conditions. The results of the study may serve as the basis for regulation of the forest cover of northern Eurasian river basins in order to obtain the desired hydrological effect depending on environmental and economic conditions.
\end{abstract}

Keywords: River runoff, Catchments, Forest cover, Geographic zoning, Central Siberia

\footnotetext{
*Correspondence: onuchin@ksc.krasn.ru; shvidenk@iiasa.ac.at

${ }^{1} V . N$. Sukachev Institute of Forest, Siberian Branch of the Russian Academy of

Sciences 660036, Academgorodok, 50/28, Russia 31, Krasnoyarsk, Russia

Full list of author information is available at the end of the article
}

\section{Springer Open}

(- The Author(s). 2021 Open Access This article is licensed under a Creative Commons Attribution 4.0 International License, which permits use, sharing, adaptation, distribution and reproduction in any medium or format, as long as you give appropriate credit to the original author(s) and the source, provide a link to the Creative Commons licence, and indicate if changes were made. The images or other third party material in this article are included in the article's Creative Commons licence, unless indicated otherwise in a credit line to the material. If material is not included in the article's Creative Commons licence and your intended use is not permitted by statutory regulation or exceeds the permitted use, you will need to obtain permission directly from the copyright holder. To view a copy of this licence, visit http://creativecommons.org/licenses/by/4.0/. 


\section{Background}

Moisture circulation processes contribute to the specificity of geosystem components, particularly to river runoff formation which is substantially determined by geographical zonality (Sokolov and Chebotarev 1970). At the same time, runoff and river flow formation are also controlled by azonal factors including, among others, soil, vegetation, geological structure, topography, and availability of permafrost (Lvovich 1963). Azonal factors sometimes negatively effect zonal factors. According to Voskresenskii (1962), the influence of local or azonal factors can substantially (up to $100 \%$ and sometimes more), deviate hydrological characteristics, particularly of small rivers, from typical zonal parameters in the same geographical area. By azonal factors, Befani and Melnichuk (1967) mean the morphometric characteristics of rivers and their watersheds (for example, river length, catchment area), independently of the geographical location of river basins. According to Lvovich (1963), the size of catchment area is not a direct generic factor in river flow formation but affects the redistribution of runoff in time and space. Together with the geological structure, the incision depth of river valleys or talveg streams, the catchment sizes determine the degree of drainage of groundwater; therefore, with a decrease in the catchment area, runoff decreases. According to studies (Zaikov 1954; Vladimirov 2009; Burakov 2011), the influence of the size of the catchment area is noticeably affecting the annual distribution of runoff, especially the formation of spring and rain floods. They consider the larger the basin area, the more evenly the river flow is distributed throughout the year; flood peak is reduced. However, no significant effect of the catchment area on the annual runoff was revealed. These authors did not identify a significant impact of the catchment area on annual runoff.

Forest vegetation is one of important azonal factors. Forest ecosystems significantly affect water balance structure and moisture redistribution between evapotranspiration and runoff (Molchanov 1960; Izon and Pimenova 1975; Schleppi 2011; Ellison et al. 2012; Sun and Vose 2016). Forest vegetation controls all evapotranspiration components and impacts, thereby, river flow formation. Percentage and spatial structure of forest area of river basins are supposed to be the appropriate numerical characteristics describing such impacts. Many studies in Russia and elsewhere attempted to assess the effect of forest cover on runoff. The network for observing runoff in paired basins in various regions of the forest zone of the northern hemisphere became the basis for obtaining field data on the topic. A detailed review of these studies is given in the papers (Bosch and Hewlett 1982; Brown et al. 2005; Gu et al. 2013). Analysis of the results of hydrological studies on forest watersheds over the past two decades (Chang 2003; Scott et al. 2004; Sun et al. 2006; Wei et al. 2013; Li et al. 2017) showed that forest hydrologists have no consensus on the effect of forest cover on the total river flow. Estimates of the hydrological role of boreal forests and the characteristics of their water cycles are likely the most controversial regarding their influence on the annual runoff volume. While such estimates in tropical and deciduous temperate forests are mostly unambiguous and indicate that forests, as compared with other types of land, always evaporate more moisture, reducing river flow, conflicting results are presented in the literature for boreal forests. Boreal forests, depending on the structure of landscapes and environmental factors, are able to transform the structure of the water balance and cause a hydrological effect, which may result in both increasing and decreasing of the annual flow of rivers (Onuchin 2015). In our opinion, the ambiguity of the hydrological role of forests in high latitudes and the associated contradictions in its assessment with results from other geographical zones are due to underestimation of the specifics of the balance of snow moisture in forest and treeless areas in connection with both the landscape and climatic features of the territories (Onuchin 2015; Onuchin et al. 2018). In the long cold seasons of the north, snow moisture is mainly included in the active moisture circulation. The most important components of the water balance in winter are interception of solid atmospheric precipitation by the forest canopy, evaporation from the surface of the snow cover, horizontal redistribution of snow through wind transport and evaporation of snow during blizzards. In winter, the intensity and direction of moisture flows are not related to the productivity of the vegetation cover, but are mainly determined by the nature of the vegetation (forest, treeless space) and environmental conditions (Onuchin 2001; Onuchin 2015).

Depending on the landscape and climatic conditions, forests transform the flows of snow moisture in different ways (Onuchin 2001, 2015; Pomeroy et al. 2002; Woods et al. 2006; Veatch et al. 2009; Varhola et al. 2010; Wei et al. 2016). Over the mild and warm winters, the forest, as compared to treeless land, works as the best evaporator. This is due to two main reasons. The first reason is a decrease in the evaporation of snow moisture in open areas, because dense and wet snow is not subject to wind transport, during which time evaporation increases exponentially with increasing wind speed. The second reason is associated with an increase in snow interception through the forest canopy with increasing air temperature that is observed due to a change in the physical properties of snow - an increase in its ductility and the ability to stick together snow particles, both with each other and with tree crowns. Intercepted snow due to the roughness of the canopy has a larger evaporating 
surface than snow lying in open places and is better blown and evaporates more intensively than dense and wet snow in open areas (Onuchin 2015; Onuchin et al. 2018). In a cold climate, where, as a rule, low-density stands prevail, the forest, on the contrary, "works" as a store of snow moisture. Dry snow easily crumbles from the crowns and penetrates under the forest canopy where it is protected from blowing and intensive evaporation. At the same time, in open areas during severe winters, blizzards are activated. This leads to an increase in the tens and hundreds of times the area of the evaporating surface of the snow raised into the air and to an increase in the intensity of its evaporation in open areas compared to the forest.

Thus, it can be concluded that with the changing background climatic conditions and phytocenotic structure of forests, their hydrological role also changes. In cold climates, a decrease in forest cover leads to the activation of snowstorms, increased evaporation of snow and, as a result, to a decrease of the total runoff. In warm and humid climates, where forest productivity is higher, on the contrary, the forest, as compared to treeless land, works as the best evaporator. This is due to two main reasons - the lack of wind transport and, as a result, a decrease in the evaporation of snow moisture in open areas and an increase in the interception of solid atmospheric precipitation by the canopy of highly productive dense stands. Forest under such conditions becomes a factor, which reduces the river flow.

Availability, zonal and landscape features of permafrost also control river flow. Forests in most of the continental zone of central Siberia are located in areas with insufficient amount of precipitation during the growth period, and formed a coupled forest - permafrost system, the trees of which use water of the active layer melting (Osawa et al. 2010). Significant part of this water is excluded from river flow. Very likely, the briefly described above specifics and complexity of hydrology of forested catchments in high latitudes were one of reasons of disparity in conclusions of some previous studies.

In this study we attempt to evaluate major factors, which control river flows in northern geographical zones of Central Siberia, basically considering latitudinal - zonal aspect. The major objective of this study is to identify the impact of share of forest area over catchments of the most northern three geographical zones of Central Siberia - forest tundra, northern, and middle taiga. Understanding of the influence of forest area on runoff of rivers of northern territories of Central Siberia is a background for achieving hydrological effects, which would be desirable within the sustainable forest management paradigm taking into account specifics of these areas.

\section{Materials and methods}

\section{Study area}

Central Siberia stretches thousands of kilometers northsouthward and possesses many specific climatic, ecologic and forest management features. The region encompasses several geographical zones and diverse landscape formations (Fig. 1). Forests of the region are presented by typical boreal tree species with dominance of coniferous (Larix sibirica and L. gmelinii, Pinus sylvestris and $P$. sibirica, Picea obovata, and Abies sibirica). Major part of this territory is covered by diverse landscape forms and continuous permafrost. We have selected nine rivers, the catchments of which are situated in the mentioned above geographical zones with the longest available observation runoff periods - from 18 to 53 years. The basins ranged from small, like the Graviyka River basin of $377 \mathrm{~km}^{2}$, to large, $240,000-\mathrm{km}^{2}$ basin of the Podkamennaya Tunguska River, one of the main tributaries of the Yenisei River (Reference Surface water resources of the USSR 1973; Central Siberian Department for Hydrometeorology and Environmental Monitoring Federal State Budgetary Institute 2015). The rivers are presented by two types: West-Siberian type of plain terrain, with slow flow and basins with numerous bogs and lakes, and East-Siberian one, usually formed in mountains, with stone beds and rapid flows. A short description of hydrological regimes and catchments of the rivers is presented in Supplementary Information (SI) and Table 1.

\section{Data source}

The boundaries of the river basins and several raster layers that describe the hydrological characteristics of the territory were determined using ArcGIS tools. To assess the temporal dynamics of forest cover of the catchment areas, related thematic forest maps were used (Forest Map of Krasnoyarsk Region 1963; Map of Forests of YSSR 1990). Forest cover was presented using ArcGIS 10.0 software (Esri 2017). Analysis of data of the forest map of the Krasnoyarsk Territory and the forest map of Russia was carried out using the Zonal Histogram tool from the Spatial Analyst package. The data obtained are compared with the attribute table, which contained the percentage of pixels of the forest cover to the total number of pixels of the total area of the river basin. The Landsat ETM+ images (spatial resolution of $30 \mathrm{~m}$, spectral bands $0.45-0.52,0.52-0.60,0.63-0.69,0.76-0.90$, $1.55-1.75$ and $2.08-2.35 \mu \mathrm{m}$ ) were used to determine the forest cover of the watersheds for 2015. The images were vectored and exported to the ArcGIS 10.0 format. The ArcGIS Spatial Analyst add-on module made it possible to perform integrated vector-raster analysis using the "Zone Statistics" tool to determine the areas occupied by different types of vegetation in the territory (Esri 2017). Intermediate forest cover values for 1970, 1975, 


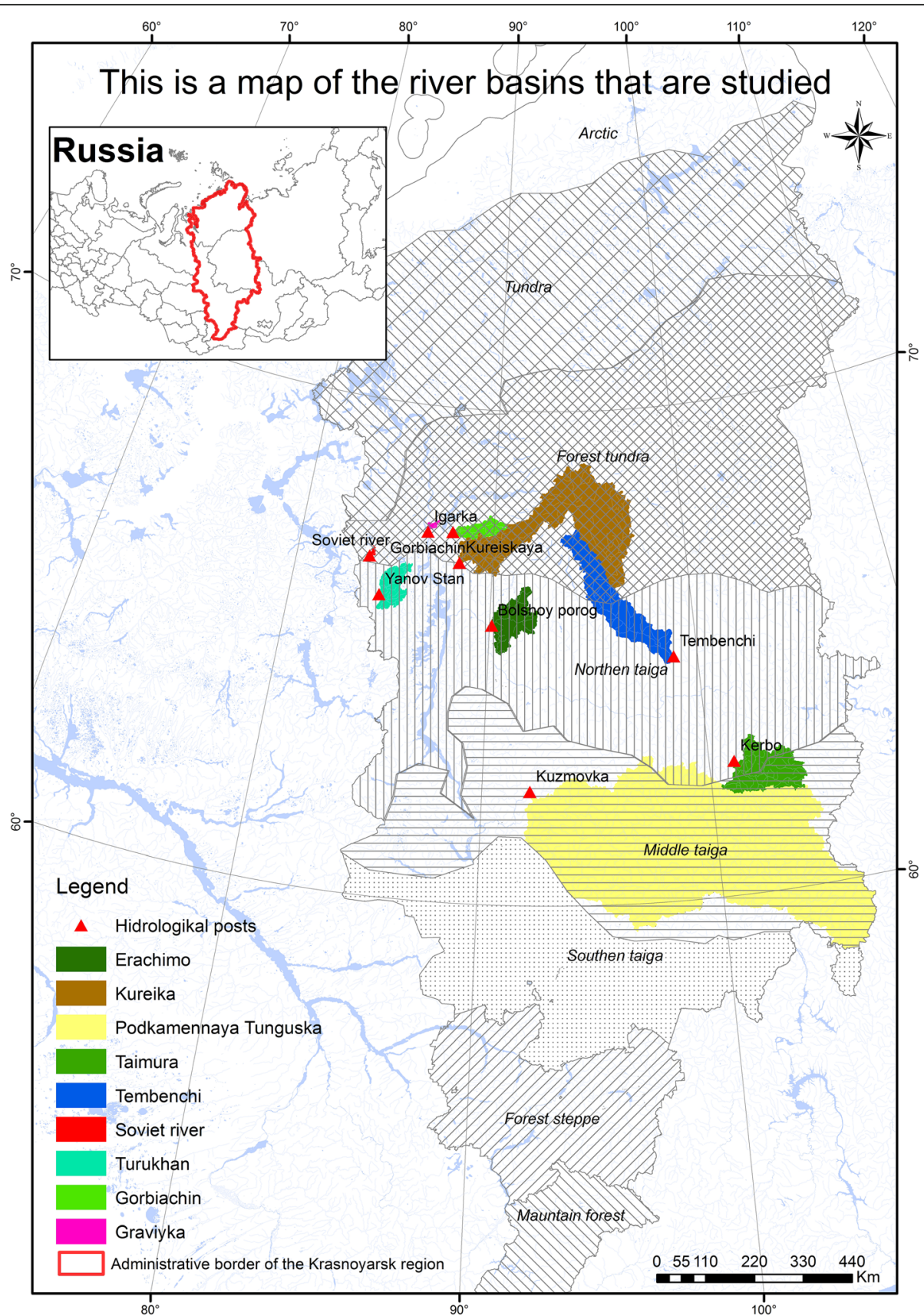

Fig. 1 Locations of the river basins

1982, 1993, 1994, 1998, 2000 and 2012 were used to model the relationship of runoff with forest cover in different bioclimatic zones.

To analyze the spatial distribution of climatic indicators (air temperature and precipitation), we used data from 12 weather stations, of which five stations are located in the forest-tundra zone, and seven - in the northern and middle taiga zones. For deriving statistics were used periods: for average monthly and an annual air temperature (1952-2012) and for annual precipitation (1966-2012). Thus, the observation period was from 37 years for precipitation and more than 60 years for temperature.

Regression analysis of the factors which control annual river runoff was provided based on matrices containing monthly measurements for the periods of observation (Table 1) including major climatic indicators (solid and liquid precipitation, temperature), as well as both geographical coordinates of centers and characteristics of forest cover of the catchments of each river considering 
Table 1 The main characteristics of the study area catchments

\begin{tabular}{|c|c|c|c|c|c|c|c|}
\hline & \multirow[t]{2}{*}{ Names of rivers - point observations } & \multicolumn{2}{|c|}{$\begin{array}{l}\text { Coordinates of point } \\
\text { observation }\end{array}$} & \multirow[t]{2}{*}{$\begin{array}{l}\text { Period of } \\
\text { observation (year) }\end{array}$} & \multirow{2}{*}{$\begin{array}{l}\text { Length } \\
\text { of } \\
\text { rivers } \\
(\mathrm{km})\end{array}$} & \multirow[t]{2}{*}{$\begin{array}{l}\text { Catchment } \\
\text { area }\left(\mathrm{km}^{2}\right)\end{array}$} & \multirow{2}{*}{$\begin{array}{l}\text { Average } \\
\text { altitude of } \\
\text { catchment } \\
\text { area }(\mathrm{m})\end{array}$} \\
\hline & & Latitude & Longitude & & & & \\
\hline \multirow[t]{4}{*}{ Forest tundra } & Gorbiachin - Gorbiachin & $67^{\circ} 29^{\prime}$ & $87^{\circ} 50^{\prime}$ & $1982-2000$ & 239 & 6250 & 600 \\
\hline & Graviyka - Igarka & $67^{\circ} 26^{\prime}$ & $86^{\circ} 31^{\prime}$ & 1940-1993 & 45 & 337 & 94 \\
\hline & Soviet - Soviet & $66^{\circ} 56^{\prime}$ & $88^{\circ} 20^{\prime}$ & 1975-2012 & 98 & 1820 & 120 \\
\hline & Kureika - Kureiskaya HPP & $66^{\circ} 49^{\prime}$ & $83^{\circ} 42^{\prime}$ & 1968-1998 & 888 & 44,700 & 658 \\
\hline \multirow[t]{3}{*}{ Northern taiga } & Turukhan - Factoria Yanov Stan & $65^{\circ} 58^{\prime}$ & $84^{\circ} 19^{\prime}$ & $1968-1993,1995-2012$ & 639 & 35,800 & 150 \\
\hline & Erachimo - Big Porog & $65^{\circ} 37^{\prime}$ & $90^{\circ} 00^{\prime}$ & 1968-2012 & 218 & 9140 & 375 \\
\hline & Tembenchi - Tembenchi & $64^{\circ} 56^{\prime}$ & $98^{\circ} 52^{\prime}$ & 1967-1994 & 574 & 21,600 & 75 \\
\hline \multirow[t]{2}{*}{ Middle taiga } & Taimura - Kerbo & $62^{\circ} 42^{\prime}$ & $101^{\circ} 50^{\prime}$ & 1975-1993 & 454 & 32,500 & 374 \\
\hline & Podkamennaya Tunguska - Factoria Kuzmovka & $62^{\circ} 18^{\prime}$ & $92^{\circ} 60^{\prime}$ & $1983-2012$ & 1865 & 240,000 & 510 \\
\hline
\end{tabular}

in the analysis. The regression equations (Results and discussion) are presented in an aggregated form, which contains both a model with fixed effect of included variables on the runoff for all catchments and random effect on the runoff for individual catchments.

\section{Results and discussion}

Zonal-regional distribution of hydro climatic parameters

Due to the considerable length of the studied region from north to south and the increase in the climate continentality from west to east, the average annual air and monthly temperatures vary significantly. The temperature minimum is observed in January at $-35^{\circ} \mathrm{C}$ (Tura Weather Station), the maximum in July $+17.9^{\circ} \mathrm{C}$ (Bor Weather Station). The average annual air temperature at weather stations with maximum and minimum values for this indicator varies by 9 degrees, maximum differences (12-15 degrees) are typical for spring months, and minimum (4-5 degrees) for August and September.

Changes in air temperature throughout the year have the same trends at all weather stations: an increase from February to July, and a decline from July to December. For most weather stations, the correlation of time series of annual temperature dynamics is high $(R=0.60-0.98)$. The weakest correlations in the air temperature changes are for the most distant weather stations: KhatangaBaikit (0.48), Khatanga-Bor (0.54), Khatanga-Vanavara (0.49).

Due to the fact that the studied river basins are located within two large ecoregions: the West Siberian Plain and Central, the spatial distribution of precipitation varies significantly. The main character of the precipitation fields on the West Siberian Plain is zonal, i.e. there is a decrease in precipitation to south and north of the taiga provinces, while in Central Siberia precipitation at the same latitudes decreases from west to east due to increasing climate continentality and complex orography that generates a significant mosaic in the spatial distribution of precipitation over the region (Burenina et al. 2002).

Comparison of the series of precipitation observations in the study areas shows that annual precipitation among weather stations is less correlated than average annual air temperature. For weather stations located at a short distance, the correlation coefficients are statistically significant from 0.30 to 0.71 . The most northern weather stations of Khatanga and Volochanka are characterized by a very weak, and in some cases negative correlation with other weather stations.

\section{Dependence of river runoff on climatic factors}

Individual rivers have substantially different level of annual runoff, from around $500-600 \mathrm{~mm}$ in forest tundra to around $200 \mathrm{~mm}$ in middle taiga zone (Fig. 2).

Average annual temperature significantly impacts annual river flow only in forest tundra (e.g., for River Kureika the change of annual average temperature from $10{ }^{\circ} \mathrm{C}$ to $-4{ }^{\circ} \mathrm{C}$ resulted in the increase of water flow from $\sim 200$ to $550 \mathrm{~mm}$ ). Such a trend might be explained by thawing of permafrost; it is not observed in the middle taiga catchments (SI Fig. 1).

In all geographical zones, but particularly in forest tundra - rivers of Gorbiachin, Graviyka, Soviet and Kureika - the increase of precipitation provides a clear positive trend of increasing river runoff (Eq. 1).

$$
\mathrm{RR}=a_{o}+\left(a_{1}+u_{1}\right) \times \quad \operatorname{Prec}
$$

where $a_{0}( \pm$ stand dev $)=217.0( \pm 21.3)$ and $a_{1}=0.361$ $( \pm 0.10), p$-values for both $<0.00-$ model parameters taking into account fixed effect of annual precipitation on river runoff of all catchments, $u_{1}$ - random effect of the runoff for individual catchments (corrections of 


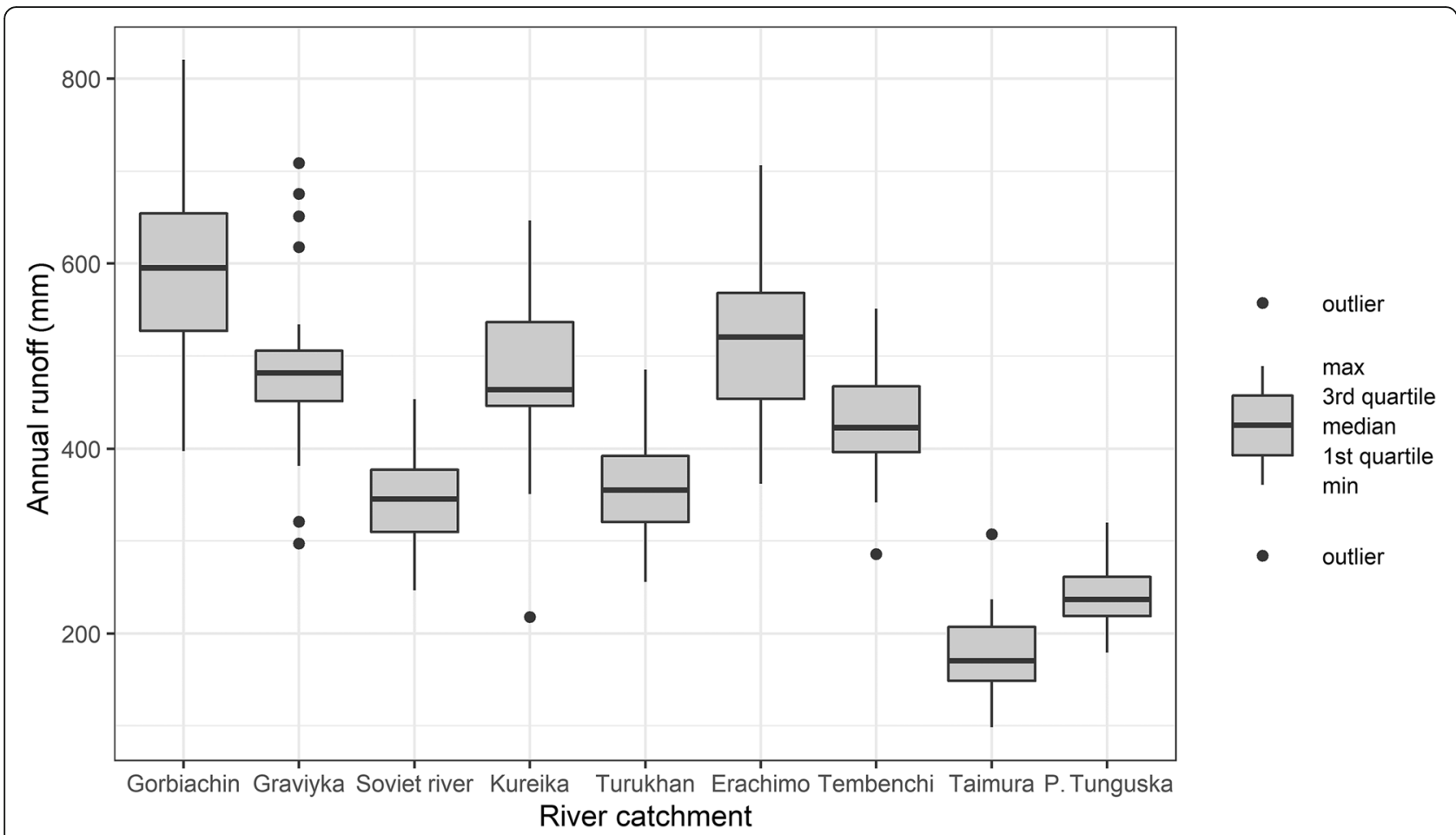

Fig. 2 Average annual runoff of the rivers considered in this study. Dots indicate outliers of specific years

coefficients $a_{1}$, see Table 4), and Prec - annual precipitation $(\mathrm{mm})$.

The trend is weaker in the south eastern part of the study region due to smaller amount of both precipitation and water of thawing permafrost (Fig. 3).

A more detailed analysis of impacts of climatic indicators on river runoff corroborates the previous statement. We used the multiple regression analysis for selected climatic indicators of individual months and seasons, as well as the runoff of the previous year (Table 2).

The obtained dependences show a reliable positive relationship between the annual runoff and the amount of precipitation (assessed based on $p$-value of $t$-statistic in system R v.4.0.3, James et al. 2013). The closest relationship is observed between annual runoff and solid precipitation. Much weaker relationship was found between the annual river runoff and the air temperature of the warm season: an increase in temperature in the summer months leads to increase of the annual river runoff. Probably, this phenomenon follows from thawing of permafrost (Onuchin et al. 2006). For some individual rivers of the northern and middle-taiga zones (Graviyka, Turukhan, Erachimo and Podkamennaya Tunguska), the decrease in annual runoff is noted with the increase in average monthly temperature in May, which is possibly associated with increased physical evaporation from surface of the snow cover and the absence of precipitation during this period (Burenina et al. 2015).
The forest cover percentage (FCP) of the major part of catchments was high and slightly increased, reaching by 2015 71\%-96\% (Fig. 4). Two catchments in forest tundra (Gorbiachin and Kureika) were an exclusion with a lower FCP (around 30\% and 40\%, typical for the southern part of the zone).

During the period of hydrological observations, runoff of individual rivers, as a rule, does not have any significant temporal trends (SI Fig. 2).

\section{The dynamics of river runoff due to change of catchments' forest cover}

Increasing forest areas over the region is likely a result of global warming that was reported in number of studies for this region (Kharuk et al. 2004; Mazepa and Shiyatov 2015). During the period after 1990s, the decrease was observed only in Kureika River basin. It is connected with the Kureika dam construction and submerging a part of the river's basin.

Increasing the forest areas of the river basins of middle and northern taiga was mostly due to intensive forest recovery after the 1914-1916 catastrophic wildfires that occurred in Central Tungus Forest Province and throughout larch forests of Central Siberia of the total area of several hundred million hectares (Dvinskaya et al. 2005). In subsequent years, the forests of northern and middle taiga zones often experienced wildfires, but these were basically local fire events of the long return 


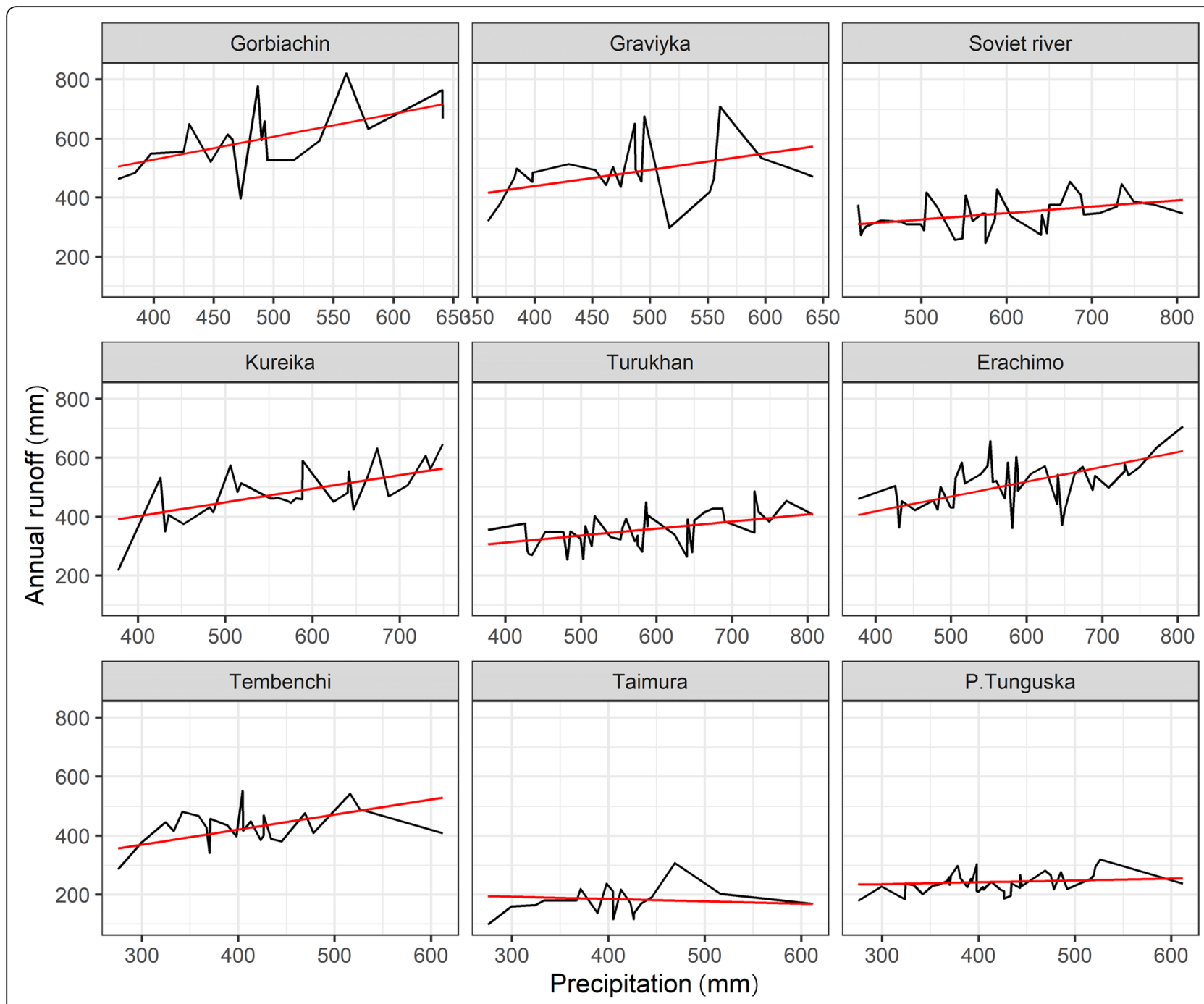

Fig. 3 Linear regression equations between annual amount of precipitation and river runoff. All coefficients of trends are statistically significant. Coefficients of trend equations for individual catchments are presented in Table 4

Table 2 Models of dependence of climatic indicators on annual runoff of individual rivers

\begin{tabular}{|c|c|c|c|c|c|}
\hline No. & River & Model & $R^{2}$ & G & $F$ \\
\hline 1 & Gorbiachin & $R R=-517.5+0.69 X_{j}+2.9 X_{t}+5.7 T_{7}$ & 0.84 & 46.3 & 28.1 \\
\hline 2 & Graviyka & $R R=62.7+0.50 X_{j}+1.1 X_{t}-12.2 T_{5}$ & 0.46 & 76.7 & 14.3 \\
\hline 3 & Soviet River & $R R=157.9+0.26 X_{j}+0.41 X_{t}-10.1 T_{5}$ & 0.30 & 46.6 & 4.9 \\
\hline 4 & Kureika & $R R=-6.3+0.9 X_{j}+9.4 T_{9}+0.00108\left(Y_{p} X_{t}\right)$ & 0.63 & 60.4 & 15.1 \\
\hline 5 & Turukhan & $R R=115.3+0.39 X_{j}+0.53 X_{t}-2.69 T_{(5+6)}$ & 0.45 & 44.0 & 10.9 \\
\hline 6 & Erachimo & $R R=154.5+0.37 X_{p}+0.58 X_{j}-10.1 T_{5}$ & 0.46 & 57.5 & 11.4 \\
\hline 7 & Tembenchi & $R R=-447.7+1.5 X_{t}+32.0 T_{7}+1.7 X_{9}$ & 0.57 & 55.5 & 10.6 \\
\hline 8 & Taimura & $R R=-250.5+0.50 X_{t}+10.6 T_{7}+0.57 X_{8}$ & 0.73 & 22.7 & 13.7 \\
\hline 9 & P. Tunguska & $R R=51.3+0.15 X_{j}+0.41 X_{t}-3.2 T_{5}$ & 0.70 & 19.4 & 20.3 \\
\hline
\end{tabular}

$R R$ : the annual flow of the river, $\mathrm{mm} ; X_{j}$ : the annual amount of liquid precipitation, $\mathrm{mm} ; X_{t}$ : the annual amount of solid precipitation, mm; $X_{8,9}:$ the average monthly rainfall in August and September, mm; $Y_{p}$ : runoff of the previous year; $T_{5,6,7}$ : average air temperature respectively in May, June and July, ${ }^{\circ} \mathrm{C} ; R^{2}$ : coefficient of multiple determination; $G$ : standard error of the equations; $F$ : Fisher criterion. The equations include the statistically significant variables (0.05) 


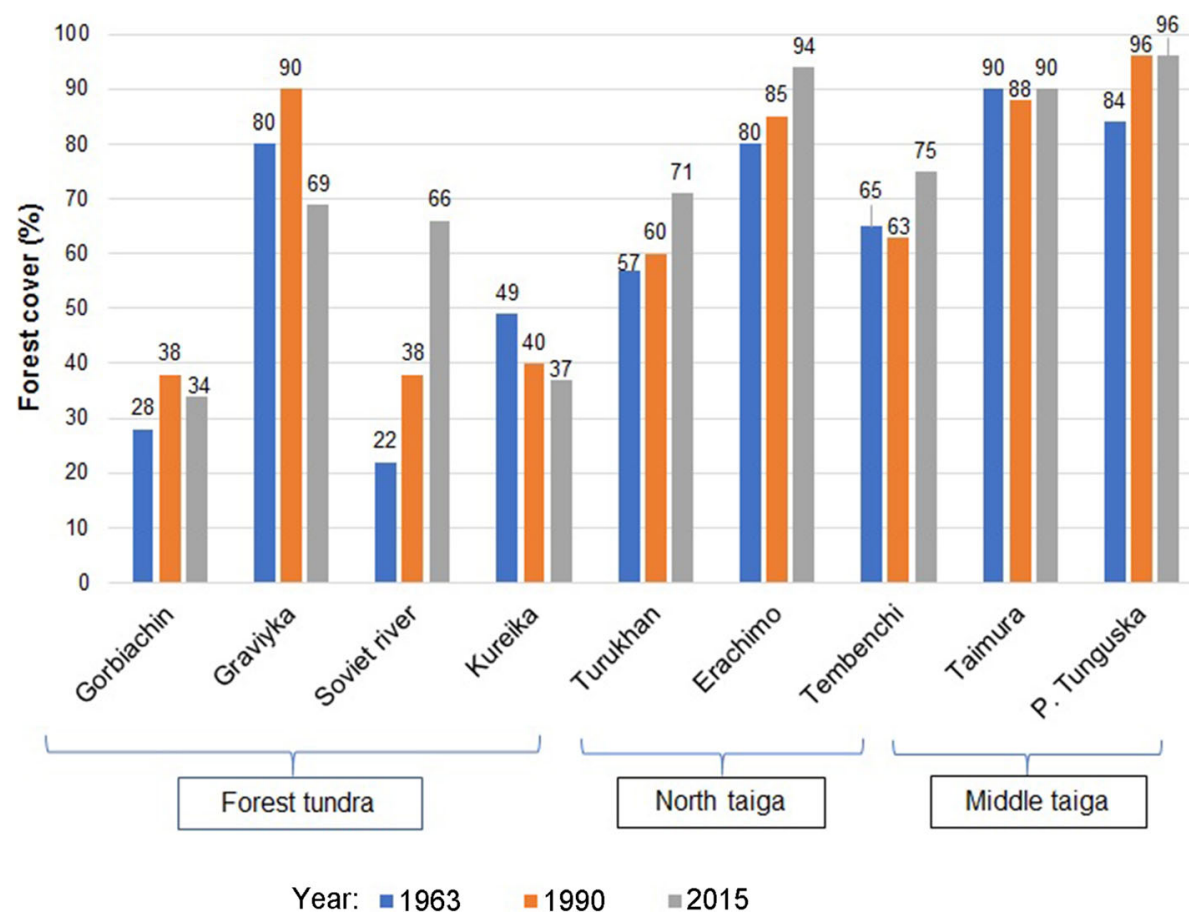

Fig. 4 Dynamics of forest cover percentage by individual catchments
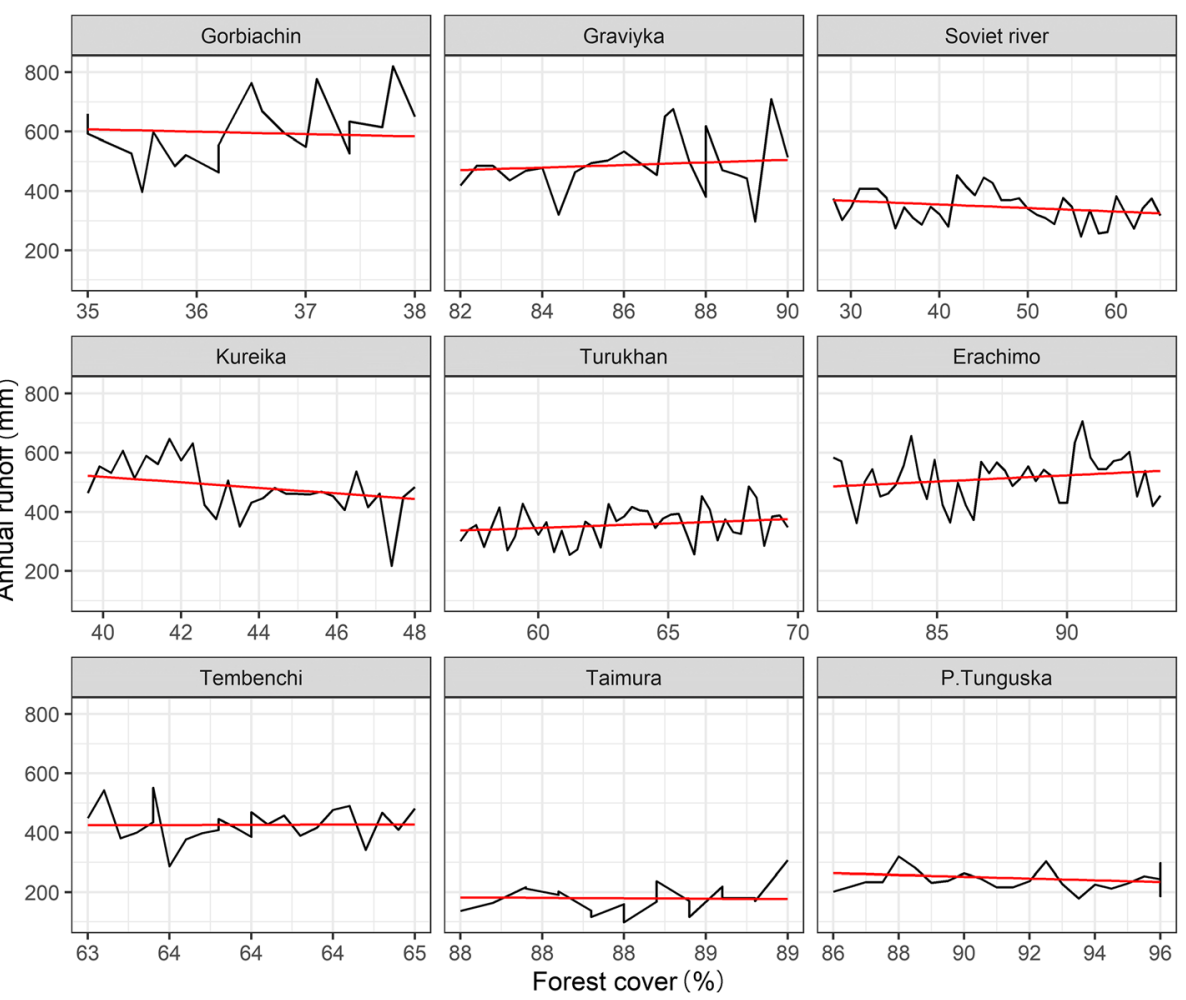

Fig. 5 Linear dependence of river runoff on forest cover percentage for individual catchments 
fire interval ranged from 66 (Ivanova 1996) to 90 years (Kharuk et al. 2008). Overall, such combinations of natural processes and anthropogenic impacts led to the transformation of the burnt areas into forests, and the FCP of the catchments remained high. As for influence of forest harvesting on changes in forest cover, this factor is not considered for the northern and middle taiga, because in these regions, industrial logging is not done due to the lack of roads.

The dynamics of river runoff due to change of catchments' forest cover in different geographical zones and large landscape formations are different and are the most pronounced in the forest tundra, where with increasing forest cover the increase in runoff is observed, is weakening and disappeared at the south (Fig. 5, Eq. 2).

The linear trend of the annual runoff as a function of FCP is.

$$
\mathrm{RR}=\left(a_{0}+u_{0}\right)+\left(a_{1}+u_{1}\right) \times \mathrm{FCP}
$$

where $a_{0}( \pm$ stand $\operatorname{dev})=462.4( \pm 134.9)$ and $a_{1}=-$ $1.592( \pm 2.178)$ - model parameters taking into account fixed effect of forest cover percentage on river flow of all catchments, $p$-value for $a_{0}$ and $a_{1}$ is equal to $7 \times 10^{-4}$ and 0.47 respectively, $u_{0}$ and $u_{1}$ - random effect of the FCP of individual catchments (corrections of coefficients of $a_{0}$ and $a_{1}$, Table 4), and FCP - forest cover percentage.

\section{Zonal aspect of impacts of forests on river runoff}

In accordance with the concept of geographical determinism in assessing the hydrological role of forests (Onuchin 2015; Onuchin et al. 2017), such phenomenon is due to the specific climatic and ecological conditions of the forest-tundra and taiga zones. In large open (treeless) areas that make up most of the forest-tundra territory, snowstorms are frequent and severe. They blow snow off these sites and enhance snow evaporation, while in the forest sites, dry and fine snow penetrates under the forest canopy, stays unmoved on the ground and its evaporation is substantially lower. Forest vegetation contributes to solid precipitation retention and, thereby, to increasing water yield (Onuchin et al. 2018). This is confirmed by the positive correlation of the forest area proportion and runoff for 3 of 4 rivers in the forest tundra (Fig. 5, untypical situation for Kureika River is explained in SI). In the middle taiga zone, where forest stands are denser and cover almost all territory of catchments, and winter air temperature is higher than in forest tundra, forest canopy intercepts more snow than at higher latitudes. Due to higher temperature, snow on open sites and below canopy becomes more compacted and more resistant to snowstorms. Evaporation here is substantially less to that in forest-tundra open sites. Actually, snow moisture balance of forest sites of the middle taiga zone becomes, to some extent, similar to that of open sites. This eliminates differences of runoff among the river with different proportions of forest area at catchments, and, therefore, no relationship of runoff with river basin forest area is identified in the middle taiga zone. As for the northern taiga zone, the correlation between runoff and river basin forest area proportion is positive, but less expressed for the forest-tundra zone (Fig. 5). All these processes and peculiarities to some extent are enhanced or weakened by other impacts, such as change in species composition of forests from almost one-species "light" larch forests in the extreme north to pine and dark coniferous forests of southern part of the middle taiga zone, or peculiarities of permafrost.

Variant analysis of multiple regressions shows model inter-dependence between indicators describing the river hydrology of the region. As an example, Table 3 contains a subset of multiple regressions of the forest flow on forest cover percentage, climatic indicators and geographical location (Eqs. 3-7).

$$
\begin{aligned}
\mathrm{RR}= & \left(a_{0}+u_{0}\right)+a_{1} \times \mathrm{LAT}+\left(a_{2}+u_{2}\right) \\
& \times \mathrm{FCP} \\
\mathrm{RR}= & a_{0}+a_{1} \times \mathrm{LAT}+\left(a_{2}+u_{2}\right) \times \mathrm{Prec} \\
\mathrm{RR}= & a_{0}+a_{1} \times \mathrm{LAT}+\left(a_{2}+u_{2}\right) \times \mathrm{Prec} \\
& +\left(a_{3}+u_{3}\right) \times \mathrm{FCP} \\
\mathrm{RR}= & a_{0}+a_{1} \times \mathrm{LAT}+a_{2} \times \mathrm{LNG} \\
& +\left(a_{3}+u_{3}\right) \times \mathrm{PREC} \\
\mathrm{RR}= & a_{0}+a_{1} \times \mathrm{LAT}+a_{2} \times \mathrm{LNG} \\
& +\left(a_{3}+u_{3}\right) \times \mathrm{PREC}+\left(a_{4}+u_{4}\right) \times \mathrm{FCP}
\end{aligned}
$$

where FCP, LAT, LNG, Prec - forest cover percentage, latitude, longitude (both degree) and annual precipitation, respectively; $a_{0}-a_{4}-$ coefficients of the equations, and $u_{1}-u_{4}-$ corrections for individual catchments (random impacts, coefficients for Eqs. 3-7 are given in Table 4).

Analysis of residuals showed a high adequacy of all models. The statistical significances of the variables with respect to impact on runoff, as a rule, decreased in the following order Prec $\rightarrow$ LAT $\rightarrow \mathrm{FCP} \rightarrow$ LNG. For Eq. 7 $p$-values for the above variables were $0.00,0.03,0.49$ and 0.20 , i.e. 4-dimensial model does not have any advantages comparatively with 3-dimensional model (Eq. 5). Information criteria (Table 3) show that there is no substantial difference in quality of predictions between twoand three-dimensional models that allow using relatively simple models. 
Table 3 Linear mixed-effects of multi-dimensional regression models

\begin{tabular}{|c|c|c|c|c|c|c|c|c|c|}
\hline \multirow[t]{2}{*}{ Model } & \multirow[t]{2}{*}{ Variables } & \multicolumn{5}{|c|}{ Parameters } & \multicolumn{3}{|c|}{ Statistics } \\
\hline & & $a_{0}$ & $a_{1}$ & $a_{2}$ & $a_{3}$ & $a_{4}$ & AIC & BIC & logLik \\
\hline 3 & LAT, FCP & -3705.4 & 62.576 & 0.553 & - & - & 3218.6 & 2236.7 & -1604.3 \\
\hline 4 & LAT, Prec & -1564.5 & 27.403 & 0.367 & - & - & 3154.8 & 3172.9 & -1572.4 \\
\hline 5 & LAT, Prec, FCP & -1674.9 & 29.145 & 0.365 & -0.1070 & - & 3156.3 & 3185.4 & -1570.2 \\
\hline 6 & LAT, LNG. Prec & -2690.9 & 38.327 & 4.624 & 0.3626 & - & 3150.7 & 3172.5 & -1569.3 \\
\hline 7 & LAT, LNG, Prec, FCP & -4820.2 & 61.961 & 11.54 & 0.3570 & -0.614 & 3151.5 & 3184.1 & -1566.7 \\
\hline
\end{tabular}

AIK Akaike information criterion, BIC Bayesian information criterion, logLic Likelihood ratio test

There are a few studies that considered the zonal aspect of impacts of forests on river runoff.

Sun et al. (2006) analyzed the correlation of forest area proportion with water yield in different parts of China within large-scale programs of forest planting and presented models of river flow response to increasing FCP. By geographical zones, increasing FCP over river basins leads to decreasing runoff by $300 \mathrm{~mm}$ for the Chinese tropical forest zone vs. $50-100 \mathrm{~mm}$ for northern cool forests. These findings are in line with the results of our analysis that revealed the trend of decreasing water flow with increasing FCP in the north-southward directions.

Available experimental data and multidimensional linear equations are not able to describe regional details of the impact of FCP on river runoff over the large and heterogeneous study area.

The zonal specificity of the hydrological functions of the forest is well approximated by a non-linear function (Eq. 8). The results obtained (Fig. 6) can be used in forestry practice presenting important information for optimizing spatial structure of forest landscapes.

$$
\mathrm{RR}=-6138.9+79.3 \mathrm{LNG}+82.9 \mathrm{LAT}^{(1-1 / \mathrm{FCP})}-67.3 \mathrm{LNG}^{(1-1 / \mathrm{FCP})}
$$$$
R^{2}=0.86, G=86.4, F=141.5 \text {, }
$$

where LAT and LNG are geographical coordinates, FCP is forest cover percentage, $R^{2}$ multiple coefficient of determination, $G$ standard equation error and $F$ Fischer criterion.

In the Eq. 8, geographical coordinates in an indirect form aggregate impacts of climatic factors. This equation approximates the available experimental data much better than other, particularly linear multiple regression. Overall, the river runoff in Central Siberia increases with increasing FCP in forest-tundra, whereas it tends to decrease to the south, particularly in the middle taiga.

According to the current understanding of the considered problem (Sokolov and Chebotarev 1970), many hydrological characteristics, such as runoff coefficient, ratio between winter and annual runoff, rivers' regime and their nutrition are zonal. Despite the fact that the basins of the studied rivers are located in different geographical zones of Central Siberia, the rivers have a similar hydrological regime for the seasons of the year: high floods in spring and low water in summer and winter. In the study region, the main share of runoff (up to $90 \%-95 \%$ ) of the annual falls is during the warm period of the year, i.e. winter low water runoff does not exceed $10 \%$, and for individual rivers, such as Tembenchi, the average long-term winter runoff may do not exceed $3 \%$ of the annual. The floods, which usually lasts from May to July, accounts for $60 \%-70 \%$ of the annual runoff. On some rivers, such as Taimura, Erachimo, the peak of flood occurs in May; on Podkamennaya Tunguska - in May or June, and for the rest of the rivers - in June-July.

Table 4 Random effect of linear dependence between river flow of individual catchments and model variables

\begin{tabular}{|c|c|c|c|c|c|c|c|c|c|}
\hline \multirow[t]{3}{*}{ Catchment } & \multirow{3}{*}{$\begin{array}{l}\text { (1) } \\
u_{1}\end{array}$} & \multicolumn{8}{|c|}{ Correction for random effect of the FCP of individual catchments for models (1)-(5) } \\
\hline & & \multicolumn{2}{|l|}{ (2) } & \multirow{2}{*}{$\begin{array}{l}\text { (3) } \\
u_{2}\end{array}$} & \multirow{2}{*}{$\begin{array}{l}\text { (4) } \\
u_{2}\end{array}$} & \multicolumn{2}{|l|}{ (5) } & \multicolumn{2}{|l|}{ (7) } \\
\hline & & $u_{0}$ & $u_{1}$ & & & $u_{2}$ & $u_{3}$ & $u_{3}$ & $u_{4}$ \\
\hline Gorbiachin & 0.4189 & 422.6 & -6.337 & 2.3671 & 0.3014 & 0.2613 & 0.4939 & 0.2006 & -0.2896 \\
\hline Graviyka & 0.1944 & -346.3 & 5.922 & -0.5098 & 0.0791 & 0.0174 & 0.4114 & -0.0072 & 0.4343 \\
\hline Kureika & 0.1018 & 429.2 & -7.735 & 0.6535 & 0.0499 & 0.1112 & -0.8118 & 0.1467 & -1.5087 \\
\hline P. Tunguska & -0.2991 & 51.33 & -1.316 & 0.8189 & -0.0470 & -0.0833 & 0.3302 & -0.0897 & 1.0283 \\
\hline Soviet River & -0.1434 & -59.30 & 0.394 & -2.1738 & -0.1929 & -01267 & -0.8252 & -0.0769 & -0.4066 \\
\hline Taimura & -0.4404 & 240.0 & -4.360 & -0.5000 & -0.2490 & -0.1130 & -0.5125 & -0.0659 & 0.8016 \\
\hline Tembenchi & 0.1487 & -130.1 & 3.056 & 0.4899 & 0.1414 & 0.0318 & 0.8200 & -0.0132 & 1.4187 \\
\hline Turukhan & -0.1223 & -298.4 & 4.628 & -1.6105 & -0.1726 & -0.1139 & -0.4983 & -0.0908 & -0.3408 \\
\hline Erachimo & 0.1414 & -313.0 & 5.749 & 0.4647 & 0.0901 & 0.0152 & 0.5923 & -0.0034 & 0.4661 \\
\hline
\end{tabular}




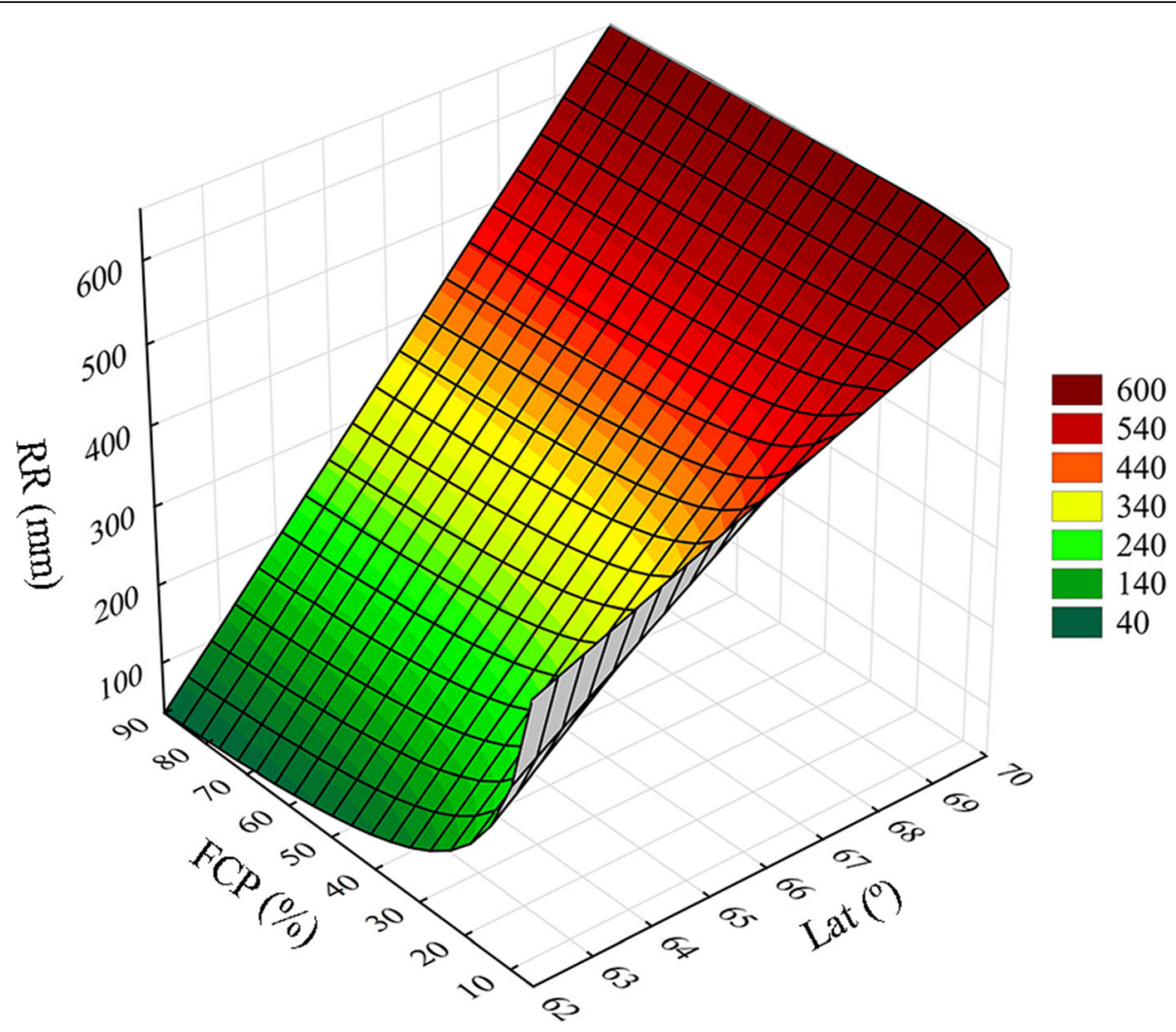

Fig. 6 Relationship of annual runoff with forest cover and geographical latitude. RR is the annual runoff, mm; FCP - forest cover of watersheds, \%; LAT, ${ }^{\circ}-$ latitude, deg. Fig. 6 illustrates dependence of the river runoff on forest cover change for the latitudes from $62-70^{\circ} \mathrm{N}$ and longitude of $83^{\circ} \mathrm{E}$

Diverse and important role in specifics of formation of river runoff in high latitudes plays permafrost.

The analysis of the data shows that changes in climatic conditions in geographical zones have an effect on the water regime of watercourses, but to a large extent it depends on local conditions, in particular, on the forest cover of the watersheds and biometric characteristics of the stands. In the forest-tundra zone, where the forest cover is usually around 20\% and less in its northern part, the stands are represented by larch light forests; the total evaporation here exceeds $50 \%$ of the total precipitation, which is most likely due to significant evaporation losses in the winter. An increase in forest cover and the presence of dark coniferous trees in the stands contribute to decrease in total evaporation and to increase of runoff.

Overall, our study confirms that the hydrological effect caused by changes of forest cover of the watersheds in high latitudes of Northern Asia reveals in increase and decrease in river flow, depending on geographical locations of catchments. The proposed models allow assessing the trends in river flow in connection with the dynamics of forest cover at the zonal level and could be used for spatial planning of distribution of forest management operations.

\section{Conclusions}

Analysis of the annual river runoff in the high latitudes of Central Siberia showed that its response to changes in the forest cover of river basins depends on the geographical latitude. This result was confirmed by numerical experiments with models based on long-term data on flow dynamics in nine catchments located in the northern geographical zones of Northern Eurasia. Numerical experiments with the obtained models showed that an increase in the forest cover of the river basin in northern latitudes contributes to an increase in runoff, but in more southern regions - to its decrease. In other words, in the zonal aspect the influence of the forest cover of catchments on the runoff is manifested more significantly in the forest-tundra than in the northern and middle taiga zones.

Thus, forest ecosystems, depending on their spatial distribution and environmental conditions, can transform hydro-climatic factors in different ways, including an ambiguous effect on the hydrological regime of 
territories. This is consistent with the concept of geographic determinism, which explains the contradictions in assessing the hydrological role of forests in different geographic and climatic conditions (Onuchin 2015; Onuchin et al. 2018). Different interpretations of the hydrological role of boreal forests are underestimating the peculiarities of the balance of snow moisture in different climatic conditions. Our models describe only general annual runoff relationships with river basin FCP and do not cover, in details, other water yield controls, such as thermal regime, precipitation, and geomorphological characteristics in an explicit form. Nonetheless, the estimates of this study may help to achieve environmentally and economically desirable hydrological regimes under different types of forest management and contribute, thereby, to sustainable forest management in critical climatic conditions under rapid climate change.

The results may be of interest for understanding hydrological consequences of climate change, particularly taking into account expected changes of both boundaries of the northern geographical zones and forest cover of catchments due to human activities and natural disturbances.

\section{Supplementary Information}

The online version contains supplementary material available at https://doi. org/10.1186/s40663-021-00316-w.

\section{Additional file 1.}

\section{Acknowledgements}

Not applicable.

\section{Authors' contributions}

The idea of research belongs to AO, TB, DP. AM developed the database. TB and DP made a literature review and data processing. Statistical treatment, analysis of the results and the writing of the paper were made by $A O, T B, A S$ and DP. The authors read and approved the final manuscript.

\section{Funding}

This work was supported by the basic project of the IF SB RAS "Theoretical Foundations of Preserving the Ecological and Resource Potential of Siberian Forests under the Conditions of Increasing Anthropogenic Press and Climate Anomalies", No. AAAA-A17-117101940014-9 (0356-2019-0027). The reported study was funded by RFBR (project number 20-05-00095).

\section{Availability of data and materials}

The datasets generated and/or analyzed during the current study are not publicly available because they are owned by different institutions. Nevertheless, they are available from the authors on reasonable request.

\section{Declarations}

Ethics approval and consent to participate Not applicable.

\section{Consent for publication}

Not applicable.

\section{Competing interests}

The authors declare that they have no competing interests.

\section{Author details}

${ }^{1}$ V.N. Sukachev Institute of Forest, Siberian Branch of the Russian Academy of Sciences 660036, Academgorodok, 50/28, Russia 31, Krasnoyarsk, Russia. ${ }^{2}$ International Institute for Applied Systems Analysis, A-2361 Laxenburg, Austria.

Received: 28 August 2020 Accepted: 25 May 2021

Published online: 07 July 2021

\section{References}

Befani AN, Melnichuk ON (1967) Calculation of the flow rate of temporary streams and mountain rivers of the Ukrainian Carpathians. Hydrometeoizdat, Leningrad, Russia, pp 105-137

Bosch JM, Hewlett JD (1982) A review of catchment experiments to determine the effect of vegetation changes on water yield and evapotranspiration. J Hydrol 55(1-4):3-23. https://doi.org/10.1016/0022-1694(82)90117-2

Brown AE, Zhan L, McMahon TA, Western AW, Vertessy RA (2005) A review of paired catchment studies for determining changes in water yield resulting from alterations in vegetation. J Hydrol 310(1-4):28-61. https://doi.org/10.101 6/j.jhydrol.2004.12.010

Burakov DA (2011) Fundamentals of meteorology, climatology and hydrology. Krasnoyarsk St Agr Univ Publ, Krasnoyarsk, p 278

Burenina T, Onuchin A, Guggenberger G, Musokhranova A, Prysov D (2015) Dynamics of hydrological regime in permafrost zone of Central Siberia. Environ Chem Biol 90:125-132

Burenina TA, Onuchin AA, Stakanov VD (2002) Liquid and solid precipitation patterns. In: Pleshikov Fl, Vaganov YA, Vetrova EF (eds) Forest ecosystems of the Yenisei Meridian. Publications of the Siberian Branch of the Russian Academy of Sciences, Novosibirsk, pp 48-50

Central Siberian Department for Hydrometeorology and Environmental Monitoring Federal State Budgetary Institute (2015) http://meteo.krasnoyarsk. ru/. Accessed 1 Dec 2015

Chang M (2003) Forest hydrology: an introduction to water and forests. CRC, Boca Raton, p 373

Dvinskaya ML, Kharuk VI, Ransone KD (2005) Cinder in larch forests of Central Siberia: time trends and landscape confinement. Modern Prob Remote Sensing Earth Space 2(2):372-379

Ellison D, Futter MN, Bishop K (2012) On the forest cover-water yield debate: from demand-to supply-side thinking. Glob Chang Biol 18(3):806-820. https://doi.org/10.1111/j.1365-2486.2011.02589.x

Esri (2017) ArcGIS Desktop. http://desktop.arcgis.com. Accessed 1 Nov 2017

Forest Map of Krasnoyarsk Region (1963) Scale 1:750 000. East Siberian Forest Management Enterprise

Gu WZ, Liu JF, Lu JJ, Frentress J (2013) Current challenges in experimental watershed hydrology. In: Bradley PM (ed) Current perspectives in contaminant hydrology and water resources sustainability. IntechOpen, pp 299-333. https://doi.org/10.5772/55087

Ivanova GA (1996) Extreme fire-dangerous seasons in Evenk. Sib Ecol J 1:29-34

Izon PF, Pimenova GS (1975) The effect of forests on river flows. Nauka, Moscow, p 111

James G, Witten D, Hastie T, Tibshiriani R (2013) An introduction to statistical learning with applications in R. Springer, p 426. https://doi.org/10.1007/ 978-1-4614-7138-7

Kharuk VI, Dvinskaya ML, Im ST (2008) Forest fires in Evenki. Nature 8:42-47

Kharuk VI, Im ST, Ransone KD, Naurzbaev MM (2004) Temporal dynamics of larch in ecotone of forest tundra. Rep Acad Sci Ser Geograph 398(3):1-5

Li Q, Wei X, Zhang M, Liu W, Fan H, Zhou G, Giles-Hansen K, Liu S, Wang Y (2017) Forest cover change and water yield in large forested watersheds: a global synthetic assessment. Ecohydrology 10(4):1-7. https://doi.org/10.1002/eco.1838

Lvovich MI (1963) Man and water. Transformation of water balance and river flow. Geografgiz, Moscow, p 567

Map "Forests of the USSR" (1990) 1: 2500000 scale map prepared by the Soyuzpromleskhoz forest cartography department / ed. M.G. Garsia; GUGK: Moscow, Russia.

Mazepa VS, Shiyatov SG (2015) Climatogenic dynamics of the upper limit of larch woodlands in the polar Urals over the past fifteen hundred years. Forests Russia Their Econ 55(4):4-11

Molchanov AA (1960) Hydrological role of forest. USSR Acad Sci Publ, Moscow, p 454

Onuchin A (2001) General appropriateness of snow storage in boreal forests. Proceedings of the Russian Academy of Sciences. Geogr Ser 2:80-86 
Onuchin A, Balster H, Borisova H, Blitz E (2006) Climatic and geographic patterns of river runoff formation in northern Eurasia. Adv Water Res 29(9):1314-1327. https://doi.org/10.1016/j.advwatres.2005.10.006

Onuchin AA (2015) Reasons of conceptual contradictions in assessing the hydrological role of boreal forests. Sib J Sci 2:41-54. https://doi.org/10.15372/ SJFS20150204

Onuchin AA, Burenina TA, Balzter H, Tsykalov AG (2018) New look at understanding hydrological role of forest. Sib J Sci 5:3-18. https://doi.org/1 0.15372/SJFS20180501

Onuchin AA, Burenina TA, Prysov DA (2017) Zonal-geographical features of hydrological functions of boreal forests. The all-Russian scientific conference with international participation: boreal forests: state, dynamics, ecosystem services. Karelian scientific center of RAS, Petrozavodsk

Osawa A, Matsuura Y, Kajimoto T (2010) Characteristics of permafrost forests in Siberia and potential responses to warming climate. In: Osaws A, Zyrynova O, Matsuura Y, Kajimoto T, Wein R (eds) Permafrost ecosystems. Ecological studies (analysis and synthesis), vol 209. Springer, Dordrecht, pp 459-481. https://doi.org/10.1007/978-1-4020-9693-8

Pomeroy JW, Gray DM, Hedstrom NR, Janowicz JR (2002) Prediction of seasonal snow accumulation in cold climate forests. Hydrol Process 16(18):3543-3558. https://doi.org/10.1002/hyp.1228

Reference Surface Water Resources of The USSR (1973) Hydrometeoizdat. Leningrad, Russia, p 724

Schleppi P (2011) Forested water catchments in a changing environment. In: Bredemeier M, Cohen S, Godbold DL, Lode E, Pichler V, Schleppi P (eds) Forest management and the water cycle: an ecosystem-based approach. Springer, Netherlands, pp 89-110

Scott DF, Bruijnzeel LA, Vertessy R, Calder IR (2004) Forest hydrology: impacts of forest plantations on streamflow. In: Burley J, Evans J, Youngquist JA (eds) The encyclopedia of forest sciences. Elsevier, Oxford, pp 367-377. https://doi, org/10.1016/B0-12-145160-7/00272-6

Sokolov AA, Chebotarev AI (1970) Essays on the development of hydrology in the USSR. Hydrometeoizdat, Leningrad, p 310

Sun G, Vose JM (2016) Forest management challenges for sustaining water resources in the anthropocene. Forests 7(3):1-13. https://doi.org/10.3390/f703 0068

Sun G, Zhou G, Zhang Z, Wei X, McNulty SG, Vose JM (2006) Potential water yield reduction due to reforestation across China. J Hydrol 328(3-4):548-558. https://doi.org/10.1016/j.jhydrol.2005.12.013

Varhola A, Coops NC, Weiler M, Moore RD (2010) Forest canopy effects on snow accumulation and ablation: an integrative review of empirical results. J Hydrol 392(3-4):219-233. https://doi.org/10.1016/j.jhydrol.2010.08.009

Veatch W, Brooks PD, Gustafson JR, Molotch NP (2009) Quantifying the effects of forest canopy cover on net snow accumulation at a continental, mid-latitude site. Ecohydrology 2(2):115-128. https://doi.org/10.1002/eco.45

Vladimirov AM (2009) Factors determining the occurrence of extreme discharges and flood water levels. Scientific Notes State Meteorol Univ 9:22-39

Voskresenskii KP (1962) The rate and variability of the annual river flow of the Soviet Union. Hydrometeoizdat, Leningrad, p 552

Wei X, Liu W, Zhou P (2013) Quantifying the relative contributions of forest change and climatic variability to hydrology in large watersheds: a critical review of research methods. Water 5(2):728-746. https://doi.org/10.3390/ w5020728

Wei Z, Yongping S, Ninglian W, Jianqiao H, An'an C, Jian Z (2016) Investigations on physical properties and ablation processes of snow cover during the spring snowmelt period in the headwater region of the Irtysh River, Chinese Altai Mountains. Environ Earth Sci 75(3):1-13. https://doi.org/10.1007/s12665015-5068-1

Woods SW, Ahl R, Sappington J, McCaughey W (2006) Snow accumulation in thinned lodgepole pine stands, Montana, USA. For Ecol Manag 235(1-3):202211. https://doi.org/10.1016/j.foreco.2006.08.013

Zaikov BD (1954) High floods and floods on the rivers of the USSR in historical time. Hydrometeoizdat, Leningrad, p 135

\section{Submit your manuscript to a SpringerOpen ${ }^{\circ}$ journal and benefit from:}

- Convenient online submission

- Rigorous peer review

- Open access: articles freely available online

- High visibility within the field

- Retaining the copyright to your article

Submit your next manuscript at $\boldsymbol{\nabla}$ springeropen.com 